\title{
PREJUDICE AND COMMUNICATION ETHICS CONFLICT'S RESOLUTION (PEMBACAAN M. QURAISH SHIHAB TERHADAP QS AL-HUJURAT 11-12)
}

\author{
ADON JUBAIDI \\ Universitas Islam Negeri (UIN) Sunan Ampel Surabaya \\ Email : jubaidiadon@gmail.com
}

\begin{abstract}
:
This paper discussed about Prejudice and Communication Ethics as Conflict's Resolutionin Indonesia. It will explore both Muhammad Quraish Shihab and his interpretation of Quran Sura Al-Hujurat: 11-12. Muhammad Quraish Shihab is one of Mufassir in Indonesia. Most of conflicts had been occur because the wrong and negatif prejudice about someone or spesific community. It was happened in Indonesia. There are many conflicts that reasons are simple. But, it had the big effect because misscommunication and negatif prejudice. Moreover conflicts are in social media. So, in the Quran has the solution about it. In Quran Sura alHujurat: 11-12, tell us about Ethics of Communication and Prejudice, that was explained by Muhammad Quraish Shihab in his Tafsir, Al-Misbah.
\end{abstract}

Keywords : Prejudice and Communication Ethics, Conflict's Resolution, Muhammad Quraish Shihab

\section{PENDAHULUAN}

Pada beberapa dekade terakhir ini, telah banyak kita saksikan beragam peristiwa dan konflik yang terjadi. Berbagai latar belakang permasalahan yang memicu terjadinya konflik tersebut. Di antaranya ialah perbedaan suku, ras, bahkan agama pun diduga sebagai penggerak utama.Hal ini bukan hanya sekedar ilusi ataupun praduga sementara, melainkan sebuah realita yang tidak bisa lepas dari keberadaan konflik.

Sebut saja Konflik Poso, peristiwa kesalahpahaman yang terjadi bertahuntahun tanpa ujung yang jelas.Menjadikan masyarakatnya terombang-ambing pada masalah perbedaan dan dendam yang tidak berkesudahan. Hingga akhirnya selesai dengan sendirinya, diakibatkan rasa 'bosan'. Ada beberapa faktor yang memengaruhi mencuatnya dan bertahannya konflik Poso tersebut. Pertama, agama-sebagai kambing hitam-yang difanatikkan oleh oknum tertentu. Kedua, perkelahian antar individu dan masyarakat yang berbeda agama. Dan ketiga, 
adanya indikasi-indikasi keterkaitan kepentingan tertentu.

Selain Konflik Poso, ada beberapa peristiwa lain yang terjadi di Indonesia. Seperti kasus Madura-Sampit yang sempat menggoncangkan Kalimantan. Adapula konflik Sunni-Syiah di Madura, yang dipicu oleh perbedaan internal dari Agama Islam. Dan yang tejadi akhir-akhir ini terkait kasus penistaan agama, yang menuai kontroversi berkelanjutan hingga ke meja sidang.

Terlepas dari segala sesuatu yang melatarbelakanginya, peristiwa-peristiwa tersebut memiliki satu akar kunci penyulut kobaran api perselisihan, yakni perbedaan. Perbedaan di antara umat manusia, khususnya di Indonesia menjadi sesuatu yang lumrah-dalam arti kata banyak-jika dilihat dari berbagai segi. Konflik terjadi di tengah kekayaan suku, bahasa serta agama yang ada di Indonesia. Hubungan antar umat beragama dan antaretnis pun memiliki tantangan tersendiri untuk menyikapinya. Hal ini disebabkan, konflik-konflik yang muncul di tengah masyarakat cenderung bernuansa SARA (Suku, Agama, Ras dan Antargolongan). Konfllik SARA yang direkam secara tertulis antara lain: Kasus Kerusuhan Sosial di Banjarmasin: 1997, Tragedi Poso; 1998-2001 (Desember 1998, April 2000, Mei 2000 dan Oktober 2001), Kerusuhan Kupang; 30 Nopember 1998, Kerusuhan Lampung; Oktober 2002, Kerusuhan Ambon; 19981999, Tragedi Berdarah Kota Waringin Timur yang melibatkan Dayak-Madura; 1999, Kerusuhan Situbondo; 1996, dan Kerusuhan Sampang; 2012. ${ }^{1}$

Kajian terhadap kerusuhan dan konflik kini mulai berkembang, mulai dari pemuka agama hingga akademisi menaruh perhatian lebih. Hasil dari penelitian dapat disimpulkan sebagai berikut: pertama, keragaman itu bersifat mutlak; kedua, keragaman tidak termasuk faktor pemicu konflik; ketiga, oknum dan etika komunikasi merupakan faktor utama pemicu konflik. Sebagai contoh Konflik Poso memiliki beberapa fase kerusuhan, fase I terjadi pada 25 Desember 1998, pemicu konflik dilakukan oleh oknum tertentu, yang menyebabkan pertikaian

\footnotetext{
${ }^{1}$ Kasus kericuhan dan kekerasan tersebut didokumentasikan oleh para jurnalis, yang kemudian dikaji kembali oleh Badan Litbang Agama Indonesia. Lihat, Departemen Agama RI, Konflik Sosial Bernuansa Agama di Indonesia (Jakarta: Balitbang Agama, 2003), seri II. Lihat juga, Nur Muhammad Wahyu Kuncoro, 69 Kasus Hukum Mengguncang Indonesia (Depok: Penebar Swadaya Grup, 2012), hal. 216-237. Kamil, Pluralisme Agama dan Resolusi Konflik: Kontribusi TH. Sumarta bagi Resolusi Konflik di Maluku (Jakarta: Sedaun, 2011).
} 
beberapa orang dengan keyakinan berbeda. Kemudian dilanjutkan fase II hingga IV, berkembangnya konflik ini tidaklah lepas dari faktor yang telah dirancang oleh oknum-oknum tertentu. ${ }^{2}$

Agama seringkali diidentikkan sebagai pemicu masalah, sedangkan pada hakikatnya yang bertanggung jawab adalah agamawan. ${ }^{3}$ Menurut Sayyed Hoessein Nasr, Islam terbagi menjadi dua istilah, Islam Ideal dan Islam Realita. ${ }^{4}$ Sebagaimana dijelaskan kembali oleh Dadang, bahwa ada dua pendekatan untuk memahami agama; 1) agama dipahami sebagai suatu doktrin dan ajaran, 2) agama dipahami sebagai aktualisasi dari doktrin tersebut yang terdapat dalam sejarah. ${ }^{5}$ Aunur Rofiq dalam bukunya menjabarkan pendapat Alexander Nitikin terkait theoretical frame dalam melihat munculnya konflik, yakni material wold,social world dan cultural-spiritual world, kemudian beliau rangkum menjadi faktor politik, ekonomi, sosial, budaya dan agama. ${ }^{6}$

Faktor-faktor yang disebutkan di atas merupakan patokan umum untuk meninjau pemicu konflik. Jika diperhatikan dengan seksama, maka faktor peledak utama terdapat pada sikap dan moral masyarakat itu sendiri, terlebih dalam etika komunikasi. Meledaknya kasus Kerusuhan Poso tidak lepas dari etika di masyarakat. Pemahaman keagamaan yang kurang memadai akan memicu oknum masyarakat cenderung membesarkan masalah hingga berujung pada kerusuhan di mana-mana. Seperti yang terjadi beberapa tahun terakhir, maraknya informasi di media sosial dengan bebas menyebarkan isu-isu sengit dan hangat. media berlomba-lomba menawarkan berita menarik dan isu terhangat, kasus Faizal Muhammad Tonong: 2017, Jenderal Gatot Nurmantyo: 2017, Penghina Ibu Negara: 2017, krisis Rohingya: 2017 dan masih banyak lagi topik yang dibahas

\footnotetext{
${ }^{2}$ Lihat kembali Departemen Agama RI, Konflik Sosial bernuansa Agama di Indonesia.... Dan Nur Muhammad, 69 Kasus Hukum Mengguncang Indonesia.

${ }^{3}$ QS Yusuf: 5. Lihat juga, Charles Kimball, Kala Agama Menjadi Bencana (Jakarta: Mizan Publika, 2013).

${ }^{4}$ Sayyed Hoessein Nasr, Islam Cita dan Islam Fakta (Jakarta: Yayasan Obor, 1984).

${ }^{5}$ Dadang Kahmad, Sosiologi Agama (Bandung: Remaja Rosdakarya, 2009), hal. 148-149.

${ }^{6}$ Aunur Rofiq, TafsirResolusi Konflik: Model Manajemen Interaksi dan Deradikalisasi Beragama Perspektif al-Qur'an dan Piagam Madinah (Malang: UIN Maliki, 2011), hal. 26-28.
} 
via media, baik itu media nasional sampai media sosial. ${ }^{7}$ Etika komunikasi sangat berpengaruh terhadap keadaan Indonesia, mengingat keragaman yang melimpah ruah dari berbagai segi rentan terhadap isu-isu, ujaran kebencian dan banyak hal lainnya. Oleh karena itu, etika komunikasi perlu diperjelas dan diangkat sebagai upaya penanggulangan terhadap konflik dan pra-konflik.

Berdasarkan pemaparan sebelumnya, konflik dan resolusi konflik dapat dipahami secara utuh dengan beberapa pembacaan. ${ }^{8}$ Pertama, pembacaan Alquran terhadap keragaman. Kedua, pembacaan menyeluruh terhadap realitas serta fakta akurat dengan menanggalkan identitas diri untuk memahami konflik tersebut. ${ }^{9}$ Ketiga, pembacaan terhadap sejarah toleransi dalam Islam. Keempat, pembacaan terhadap QS Al-Hujurat ayat 11-12 sebagai penanggulangan konflik internal maupun eksternal.

\section{TINJAUAN TEORITIS}

\section{Konsep Kebhinekaan dalam Alquran}

Alquran telah menyebutkan dengan jelas terkait kebhinekaan atau keragaman.Dalam kasus ini, ayat tidak bisa dilacak menggunakan satu kata kunci, melainkan dengan melihat tema-tema pokok di dalam Alquran. Adapun ayat-ayat yang berbicara tentang keragaman ini tercantum dalam Ar-Rum: 22, Fathir: 28, Al-Baqarah: 62, 139, Al-Hajj: 17, Al-Hujurat: 13, An-Nisa: 1, Hud: 118-119, AlMaidah: 48, Al-Kafirun:1-6, Al-Mumtahanah: 8, Ali Imran: 159, Al-An'am 107, Al-Furqan 63, An-Nahl: 125dan masih banyak ayat-ayat yang dianggap membicarakan keragaman dan toleransi. ${ }^{10}$

Menurut Muhammad Chirzin, menyebutkan tentang keanekaragaman di

\footnotetext{
${ }^{7}$ lihat Tempo; Mengulik Dunia Digital Indonesia (3 September 2017), Membajak Akun Menabur Benci (3 September 2017), Dusta di atas Derita: Kabar Bohong tentang Krisis Rohingya (17September 2017), Sang Jenderal dan Kontroversinya (8 Oktober 2017),

${ }^{8}$ Pembacaan yang dimaksud adalah perenunggan dan penelaahan lihat Kutbuddin Aibak, Teologi Pembacaan: dari Tradisi Pembacaan Paganis Menuju Rabbani (Yogyakarta: Teras, 2009), hal. iii-v.

${ }^{9}$ Baca Fenomenologi. Lihat Luluk Fikri Zuhriyah, "Metode dan Pendekatan dalam Studi Islam: Pembacaan atas Pemikiran Charles J. Adams", Islamica: Jurnal Studi Keislaman, Vol. 2 No 1 September 2007, hal. 34-35.

${ }^{10}$ lihat Zuhairi Misrawi, Alquran Kitab Toleransi: Inklusivisme, Pluralisme dan Multikulturalisme (Jakarta: Fitrah, 2007). juga Muhammad Chirzin, "Keanekaragaman dalam Alquran", Jurnal Tsaqafah, Vol 7, No 1, April 2011, hal. 51-68. Fazlur Rahman, Tema Pokok Alquran, terj. Anas Mahyuddin (Bandung: Pustaka, 1980).
} 
dalam Alquran ${ }^{11}$, antara lain:

1. Keragaman Agama, (Al-Baqarah: 62, Al-Hajj: 17), Etnik (Al-Hujurat: 13, Al-Mumtahanah: 8) dan banyaknya agama yang ada di muka bumi ini, khususnya di Indonesia, membuka peluang yang lebar terkait pengamalan toleransi. Masyarakat dengan beragam agama yang hidup berdampingan di dalam suatu wilayah, dituntut untuk menjunjung tinggi nilai-nilai toleransi. Sehingga dapat terciptanya kondisi masyarakat yang harmonis. Selain di atur oleh kebijakan-kebijakan di dalam agama, Indonesia sendiri memiliki dekrit khusus untuk mengaturnya, yang terangkum di dalam perundang-undangan dan Hak Asasi Manusia. Oleh karena itu, kehadiran sosok pemuka agama dan pemerintah sangat diperlukan untuk menanamkan serta menjaga nilainilai toleransi.

2. Keragaman Etnik, berbeda tanah maka berbeda pula adat, budaya dan bahaya yang ada. Indonesia dengan ragam budaya serta bahasanya, mampu mencerminkan tingkat toleransi yang tinggi. Meskipun demikian, tetap saja perselisihan antar etnik perlu kebijakan dari pemuka agama dan pemerintah setempat. Karena tidak menutup kemungkinan, perselisihan pribadi, mampu mencuat jika diantara etnik atau pribadi tersebut memiliki perbedaan keyakinan. Dan sekali lagi, agama akan dikambing-hitamkan atas masalah yang terjadi. Meskipun, keberagamaan atau sikap fanatik oleh umat beragama itu sendiri yang menjadi penyulut kesalahpahaman.

3. Profesi (An-Naml: 17, An-Nahl: 92, Al-Baqarah: 188, An-Nisa 29, AlMukminun: 27, Al-Anbiya: 80, Thaha 18). ${ }^{12}$

Terlepas dari semua keragaman dan perbedaan yang ada, pada dasarnya

${ }^{11}$ Muhammad Chirzin, "Keanekaragaman dalam al-Qur'an,” Tsaqafah Jurnal Peradaban Islam, Vol 7, No 1, April 2011, 52-67.

${ }^{12}$ Lihat Chirzin, Keanekaragaman.... hal. 57-62. Sedangkan Fakhrie Hanif menyebutkan, toleransi terkait keragaman ini dapat dibagi menjadi dua, yaitu Agama dan Pemikiran. Lihat, Fakhrie Hanif, “Toleransi dalam Alquran”, Al-Nahdhah, Vol III No 3, 2009, hal. 104-117. 
manusia adalah makhluk yang menginginkan perdamaian. Dengan berpegang teguh pada agama dan mengikuti setiap amal saleh yang dilakukan Nabi SAW, maka kehidupan yang damai, saling menghargai, menghormati, tolong-menolong, dan kebaikan-kebaikan apapun akan terwujud. Wujud dari Islam itu sendiri sudah tercermin dari sikap toleransi, tergantung dari cara kita memperlakukan orang lain. Serta bagaimana cara kita bersikap terhadap umat agama lain, bahkan dengan sesama Islam sendiri.

Allah SWT telah menegaskan di dalam Alquran, bahwasanya keragaman itu merupakan sunnatullah. Kemutlakan yang wajib diyakini oleh seluruh ciptaan. Alquran tidak hanya menyebutkan tentang keragaman fisik, sebagaimana Firman Allah SWT dalam QS Huud: 118-119 yang artinya:

Jikalau Tuhanmu menghendaki, tentu Dia menjadikan manusia umat yang satu, tetapi mereka Senantiasa berselisih pendapat.Kecuali orang-orang yang diberi rahmat oleh Tuhanmu.dan untuk Itulah Allah menciptakan mereka. kalimat Tuhanmu (keputusan-Nya) telah ditetapkan: Sesungguhnya aku akan memenuhi neraka Jahannam dengan jin dan manusia (yang durhaka) semuanya.

Sekiranya Tuhamu menghendaki, tentu Dia menjadikan manusia satu umat yang satu, tetapi mereka senantiasa berselisih kecuali orang-orang yang diberi rahmat oleh Tuhanmu, untuk itulah Allah menciptakan mereka.

Fakhruddin ar-Razi menjelaskan manusia senantiasa berbeda dalam perkara agama, akhlak dan perbuatan. ${ }^{13}$ Manusia satu dengan lainnya memiliki banyak perbedaan. Sebagaimana yang telah disebutkan ar-Razi, bahwasanya perbedaan tersebut meliputi masalah agama serta akhlak.

Menurut Hamka, ayat ini merupakan penegasan terhadap Kekuasaan Allah dan sikap perbedaan. Jika Allah menginginkan, maka manusia itu dapat bersatu semua, akur semua, damai, tidak ada perselisihan.Akan tetapi, Allah menciptakan manusia berbeda-beda dengan tujuan khusus, yakni agar manusia dapat berfikir, saling melengkapi dan memaknai perbedaan, hanya manusia yang diberi rahmat Allah lah yang mampu menghindari perselisihan karena perbedaan. ${ }^{14}$

Sedangkan Ibn Katsir menjelaskan lebih lanjut, bahwasanya Allah mampu

${ }^{13}$ Lihat Fakhruddin ar-Razi, Mafaatih al-Ghaib (Beirut: Dar al-Fikr, 1995), hal. 78.

${ }^{14}$ Hamka, Tafsir Al-Azhar Juz XII (Jakarta: Pustaka Panjimas, 2002), hal. 152-154. 
menjadikan manusia semuanya menjadi satu umat, baik dalam keimanan ataupun kekafiran. ${ }^{15}$ Tetap saja perbedaan terjadi di antara umat manusia dalam agama, keyakinan, anutan dan sudut pandangnya.Karena perbedaan inilah, ada yang mendapat rahmat, taufik dan hidayah dari Allah, mereka bersatu dalam menyikapi perbedaan, ada pula yang tidak henti berselisih. ${ }^{16}$

Quraish Shihab memaparkan kata berarti sekiranya pada ayat di atas, menunjukkan bahwa hal tersebut tidak dikehendaki-Nya, karena kata law digunakan untuk mengandaikan sesuatu yang mustahil terjadi. ${ }^{17}$ Lanjutnya, perselisihan dan perbedaan yang terjadi di masyarakat dapat menimbulkan kelemahan serta ketegangan antar-mereka, tetapi dalam kehidupan ini ada perbedaan yang tidak dapat dihindari, yaitu ciri dan tabiat manusia yang pada dilirannya menimbulkan perbedaan-perbedaan dalam banyak hal. ${ }^{18}$ Allah ingin menunjukkan bahwasanya manusia adalah makhluk social yang tidak lepas dari perbedaan.

Dapat disimpulkan, bahwa Alquran dengan jelas telah berbicara masalah kebhinekaan.Perbadaan ras, suku, bahasa serta agama merupakan hal sunnatullah dan mutlak terjadi.Ada hikmah yang ingin Allah jelaskan dengan perbedaan ini.Meskipun, fakta di lapangan menunjukkan hal sebaliknya, meskipun tidak sebanding dengan kerukunan yang telah terjalin.Kesenjangan antara Kebhinekaan dengan fakta konflik menimbulkan suatu pernyataan baru, bahwasanya pemahaman yang belum mantap seorang agamawan terhadap agamanya dapat menimbulkan masalah-masalah di kehidupan bermasyarakat. Oleh sebab itu, pada pembahasan selanjutnya akan dibicarakan contoh fakta penghormatan Islam atas kebhinekaan. Sehingga diharapkan mampu memberikan gambaran bagaimana seharusnya bersikap dengan mencontoh perilaku terdahulu.

\footnotetext{
${ }^{15}$ Jikalau Rabbmu menghendaki, tentulah beriman semua orang di muka bumi seluruhnya.(QS Yunus: 99). Lihat Juga, Abdullah bin Ishaq, Lubaabut Tafsir Min Ibni Katsiir,terj. M. Abdul Ghoffar (Jakarta: Pustaka Imam Asy-Syafi'I, 2013), hal. 505-506.

${ }^{16}$ Lihat Departemen Agama RI, Al-Qur'an dan tafsirnya: Edisi yang disempurnakan (Jakarta: Lentera Abadi, 2010), hal. 486-489.

${ }_{17}$ M. Quraish Shihab. Tafsir Al-Mishbah: Pesan, Kesan dan Keserasian al-Qur'an (Ciputat: Lentera Hati, 2011), vol.5, hal. 784.

${ }^{18}$ M. Quraish Shihab. Tafsir Al-Mishbah...hal. 784.
} 


\section{Berkaca Kembali: Kebhinekaan dan Toleransi dalam Sejarah.}

Sejarah mencatat, Islam mengajarkan tentang penghormatan terhadap sesama manusia.Rasulullah semasa hidup banyak mengajarkan arti penting akhlak terhadap manusia.Sesungguhnya tujuan diutusnya beliau adalah untuk menyempurnakan akhlak.Di dalam catatan sejarah Islam, terdapat banyak contoh cerita yang berkaitan dengan toleransi. Mulai zaman Nabi saw hingga abad kemajuan teknologi sekarang ini.

Banyak dari sikap dan perbuatan Nabi saw, dalam setiap perbuatannya selalu mengacu pada nilai-nilai toleransi. Karena sejatinya beliau diutus ialah untuk menyempurnakan akhlak umat manusia. Nilai-nilai yang beliau tanamkan dapat kita selami dari berbagai sirah Nabi saw. Tidak hanya itu, beragam kisah di dalam al-Qur'an dan al-Hadits pun menyebutkan tentang nilai-nilai toleransi yang hakiki.

Piagam Madinah merupakan bukti konkrit undang-undang yang mengatur hubungan manusia. Piagam inilah yang digunakan Rasulullah sebagai pedoman etik dan moral bagi umat Islam di tengah masyarakat Madinah, dengan notabene dihuni berbagai suku dan agama. Kode etik inilah yang seharusnya dipegang oleh seluruh umat manusia. Piagam Madinah juga mencerminkan keadilan yang direpresentasikan sikap Rasulullah terhadap kaum Yahudi.Meskipun pada akhirnya kaum yahudi mengkhianati perjanjian tersebut. ${ }^{19}$

Selain itu, dalam sejarah Islam juga disebutkan tentang sikap Salahuddin al-Ayyubi yang begitu toleran terhadap Pasukan Perang Salib. Dalam arti, Salahuddin al-Ayyubi meskipun berperang mengalahkan Pasukan Salib, akan tetapi dia tidak menyimpan dendam terhadap mereka. ${ }^{20}$

Selanjutnya ada Klenteng Sam Pokong di Semarang. Klenteng ini merupakan saksi sejarah adanya hubungan harmonis antar-agama. Laksamana Cheng Ho menunjukkan sikap baiknya terhadap non-Muslim. Semangat toleransi

\footnotetext{
${ }^{19}$ Lihat Said Ramadhan Al-Buthy, Fikih Sirah: Hikmah Tersirat dalam Lintas Sejarah Hidup Rasulullah, terj. Fuad Syaifudin Nur (Jakarta: Mizan Publika, 2010), hal. 236-244. Juga, Zainal Abidin Ahmad, Piagam Nabi Muhammad: Konstitusi Negara Tertulis yang Pertama di Dunia (Jakarta: Bulan Bintang, 1973).

${ }^{20}$ Muhammad Abdel Haleem, Memahami al-Quran: Pendekatan Gaya dan Tema, terj. Rofik Suhud, (Bandung: Marja', 2002), 110.
} 
masih dapat dirasakan di sana. Sebut saja Laksamana Cheng Ho, dalam sejarah Indonesia nama tersebut tidaklah terdengar asing. Yang dapat dicatat sejarah dari Cheng Ho ialah tentang bagaimana usahanya mengajarkan arti toleransi dan pluralisme terhadap komunitas agama lain. ${ }^{21}$ Laksamana Cheng Ho mengajarkan kepada masyarakat sekitarnya untuk sadar bahwa konflik kekerasan dalam menghadapi agama lain bukanlah cerminan dari Islam yang rahmatal lil alamin.Islam yang sejati adalah Islam yang banyak berdialog, berbagi, mendengarkan dan tidak egois. ${ }^{22}$ Agama lain yang dimaksud adalah kumpulan agama seperti Abangan, Islam, Taoisme, dan Budha. Cheng Ho menginginkan adanya kebersamaan dan saling menghargai di antara umat beragama di sekitarnya.Hingga sekarang, rasa toleransi yang ditanamkan oleh Cheng Ho masih melekat dan dapat dirasakan di Klenteng Sam Po Kong Semarang. ${ }^{23}$

\section{Biografi Muhammad Quraish Shihab}

M. Quraish Shihab merupakan seorang figur cendekiawan muslim sekaligus pakar tafsir yang berasal dari Indonesia. Ia dilahirkan pada 16 Februari 1944, bertempat di Rappang kabupaten Sidrap (Sidenreng Rappang), provinsi Sulawesi Selatan. ${ }^{24}$ Ia berasal dari keluarga keturunan Arab-Bugis. Ayahnya Prof. Abdurrahman Shihab (1905-1986) merupakan keturunan Arab, yang selain dikenal sebagai seorang pengusaha/wiraswasta, dan politikus, juga merupakan sosok ulama/guru besar di bidang tafsir yang diakui ketokohannya oleh masyarakat banyak terkhusus di daerah Sulawesi Selatan. ${ }^{25}$ Sedangkan darahBugis

${ }^{21}$ Dian maya Safitri, "Belajar tentang Nilai-Nilai Pluralisme Islam Jenderal Cheng Ho Melalui Sinkretismed Abangan, Islam, Toisme, dan Budha di Klenteng San Po Kong," Kumpulan Makalah The $10^{\text {th }}$ Annual Conference on Islamic Studies, Banjarmasin: IAIN Antasari, 2010, 2541.

${ }^{22}$ Dian Maya Safitri, "Belajar tentang Nilai-nilai Pluralisme Islam Jenderal Cheng Ho", Kumpulan Makalah the 10 $0^{\text {th }}$ Annual Conference on Islamic Studies, Banjarmasin 1-4 November 2010, hal. 25-41.

${ }^{23}$ Dian maya Safitri, "Belajar tentang Nilai-Nilai Pluralisme Islam Jenderal Cheng Ho..., 25-41.

${ }^{24}$ M. Quraish Shihab, Lentera Hati : Kisah dan Hikmah Kehidupan, (Cet. I; Bandung : PT. Mizan Pustaka, 2014), h. 5. Lihat juga : M. Quraish Shihab, Secercah Cahaya Ilahi : Hidup Bersama AlQuran, Edisi Baru (Cet. I; Bandung : PT. Mizan Pustaka, 2007), h. 5. Lihat juga : M. Quraish Shihab, Wawasan Al-Quran, Edisi Baru (Cet. I; Bandung : 2013), h. v.

${ }^{25}$ Muhammad Iqbal, ,Metode Penafsiran Al-Qur'an M. Quraish Shihab , Jurnal Tsaqafah 6, no. 2 , Oktober (2010): h. 249-250. Lihat juga: Andi Zulfikar Darussalam, Konsep At-Tijarah dalam Tafsir Al-Mishbah Karya M. Quraish Shihab, Tesis (Program Pascasarjana UIN Sunan Kalijaga 
diperoleh melalui garis keturunan ibunya bernama Asma, yangnotabenenya merupakan seorang wanita bangsawan cucu dari raja Bugis.

Marga Shihab pada namanya dinisbahkan pada keluarga ayahnya. Marga ${ }^{26}$ tersebut secara silsilah dianggap bersambung nasabnya sampai kepada Rasulullah saw, penanda akan keturunan Nabi yang berasal dari Hadhramaut di Yaman. Dijelaskan bahwa kakek Quraish Shihab, Habib Ali bin Abdurrahman Shihab memang berasal dari tempat tersebut. Lazimnya marga ini juga digunakan di daerah Timur lainnya sepeti pada wilayah anak benua India termasuk pula Indonesia. $^{27}$

Pengenalan dan interaksi Quraish Shihab dengan wawasan-wawasan keislaman telah dimulai sejak kecil didukung oleh lingkungan keluarganya yang religius. Kondisi keluarga yang agamais muncul dipengaruhi oleh background keilmuan orang tuanya, sehingga kecintaan serta ketertarikan Quraish Shihab terhadap al-Qur'an dan tafsir sendiri telah muncul sejak kecil. Seperti yang telah disebutkan terlebih dahulu, ayahnya Abdurrahman Shihab memang dikenal sebagai seorang pakar tafsir yang berdedikasi di dunia pendidikan.Ia merupakan tokoh yang berperan sebagai pendiri sekaligus menjabat Rektor Universitas Muslim Indonesia pada tahun 1959-1965. Jabatan yang sama juga pernahdiembannya sebagai rektor di IAIN Alauddin Makassar (sekarang UIN) padatahun $1972-1977 .{ }^{28}$ Sejak berumur 6-7 tahun Quraish Shihab sudah

Yogyakarta, 2014), h. 39. Lihat juga : Muslim, Seksualitas dalam Al-Qur'an : Studi Tentang Orientasi dan Etika Seksualitas dalam Tafsir Al-Mishbah Karya M. Quraish Shihab, Tesis (Program Pascasarjana UIN Sunan Kalijaga Yogyakarta, 2013), h. 30. Lihat juga : Mubaidillah, ,Tafsir Al-Lubab Karya M. Quraish Shihab : Kajian Metodologi Tafsir Kontemporere, Jurnal Nur El-Islam 3, no. 1, April (2016): h. 197.

${ }^{26}$ Syarifah laili, Studi Analisis Ayat-Ayat Ukhuwah dalam Tafsir Al-Mishbah Karya M. Quraish Shihab, Tesis (Program Pascasarjana UIN Sumatera Utara, 2016), h. 10.

${ }^{27}$ Lihat : Ilham, Penafsiran Ayat-Ayat Perumpamaan Menurut M. Quraish Shihab dalam Tafsir AlMisbah, Tesis (Program Pascasarjana UIN Sunan Kalijaga Yogyakarta, 2010), h. 29. Lihat juga: Atik Wartini,Corak Penafsiran M. Quraish Shihab dalam Tafsir Al-Misbah', Hunafa: Jurnal Studia Islamika 11, no. 1, Juni (2014): h. 114. Lihat juga: Artik Wartini,Tafsir feminis m.Quraish shihab: Telaah ayat-ayat Gender dalam Tafsir al-misbah', Jurnal Palastren 6, no. 2, Desember (2013): h. 476.

${ }^{28}$ Lihat: Robiah Al-Adawiyah, Penafsiran Al-Alu>si dan M. Quraish Shihab Terhadap Ayat-Ayat Al-Qur'an Tentang Sabar, Tesis (Program Pascasarjana UIN Sunan KalijagaYogyakarta, 2016), h. 35-36. Lihat juga: Ilham, Penafsiran Ayat-Ayat Perumpamaan Menurut M. Quraish Shihab dalam Tafsir Al-Misbah, h. 29-30. Lihat juga : Atik Wartini, ,Corak Penafsiran M. Quraish Shihab dalam Tafsir Al-Misbahe, h. 114-115. Lihat juga : Artik Wartini, ,Tafsir feminis M.Quraish shihab: 
diharuskan untuk mengikuti kajian-kajian tafsir yang dibawakan oleh ayahnya sendiri. Bahkan pada usia sembilan tahun ia telah terbiasa menemani sang ayah dalam aktivitas akademiknya sebagai seorang pengajar. ${ }^{29}$ Di samping ayahnya, peran seorang Ibu juga tidak kalah pentingnya dalam memberikan dorongan kepada anak-anaknyauntuk giat belajar terutama masalah agama. Dorongan Ibu inilah yang menjadi motivasi ketekunan dalam menuntut Ilmu agama sampai membentuk kepribadiaanya yang kuat terhadap basis keislaman. ${ }^{30}$

M. Quraish Shihab memulai pendidikan di Kampung halamannya di Ujung Pandang, dan melanjutkan pendidikan menengahnya di Malang tepatnya di Pondok Pesantren Dar al-Hadist al-Fiqhiyyah.13 Kemudian pada tahun 1958, dia berangkat ke Kairo Mesir untuk meneruskan pendidikannya di al-Azhar dan diterima di kelas II Tsanawiyyah. Selanjutnya pada Tahun 1967 dia meraih gelarLc. (S1) pada Fakultas Ushuludin Jurusan Tafsir Hadist Universitas AlAzhar. Kemudian dia melanjutkan pendidikanya di fakultas yang sama, sehingga tahun 1969 ia meraih gelar MA untuk spesialis Tafsir Alquran dengan judul alI'jāz al-Tasyri' li al-Qur'ān al-Karīm. 14 Pada tahun 1980, M. Quraish Shihab kembali melanjutkan pendidikanya di Universitas al-Azhar, dan menulis disertasi yang berjudul Naẓm al-Durar li al-Biqaī Taḥqīq wa Dirāsah sehingga pada tahun 1982 berhasil meraih gelar doktor dalam studi ilmu-ilmu Alquran dengan yudisium Summa Cumlaude, yang disertai dengan penghargaan tingkat 1 (Mumtaz Ma'a Martabat al-syaraf al-Ula). Dengan demikian ia tercatat sebagai orang pertama dari Asia Tenggara yang meraih gelar tersebut. ${ }^{31}$

Telaah ayat-ayat Gender dalam Tafsir al-misbah', h. 476. Lihat juga Muhammad Iqbal, Metode Penafsiran Al-Qur'an M. Quraish Shihab ${ }^{\circ}$, h. 249-250.

${ }^{29}$ Artik Wartini, ,Tafsir feminis m.Quraish shihab: Telaah ayat-ayat Gender dalam Tafsir alMisbahe, h. 476. Lihat juga : Mubaidillah, Tafsir Al-Lubab Karya M. Quraish Shihab : KajianMetodologi Tafsir Kontemporer', h. 198. Lihat juga : Robiah Al-Adawiyah, Penafsiran AlAlusi dan M. Quraish Shihab Terhadap Ayat-Ayat Al-Qur'an Tentang Sabar, h. 36. Lihat juga : Ilham, Penafsiran Ayat-Ayat Perumpamaan Menurut M. Quraish Shihab dalam Tafsir Al-Misbah, h. 30 .

${ }^{30}$ Artik Wartini, ,Tafsir feminis m.Quraish shihab: Telaah ayat-ayat Gender dalam Tafsir alMisbahe, h. 114.

${ }^{31}$ Artik Wartini, ,Tafsir feminis m.Quraish shihab: Telaah ayat-ayat Gender dalam Tafsir al-

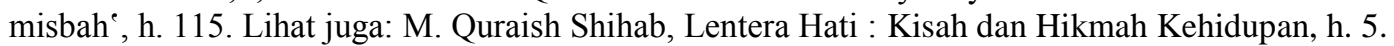
Lihat juga: M. Quraish Shihab, Secercah Cahaya Ilahi : Hidup Bersama Al-Quran, Edisi Baru,, h. 5. Lihat juga: M. Quraish Shihab, Wawasan Al-Quran, Edisi Baru, h. v. 
Setelah kembali ke Indonesia, pada tahun 1984, M. Quraish Shihab ditugaskan di Fakultas Ushuluddin dan Program Pascasarjana IAIN Syarif Hidayatullah Jakarta. Pada tahun 1995, ia dipercaya menjabat Rektor IAIN Syarif Hidayatullah Jakarta. Jabatan tersebut memberikan peluang untuk merealisasikan gagasan-gagasanya, salah satu di antaranya melakukan penafsiran dengan menggunakan pendekatan multidisipliner, yaitu pendekatan yang melibatkan sejumlah ilmuwan dari berbagi bidang spesialisasi. Menurutnya, hal ini akan lebih berhasil untuk mengungkapkan petunjuk-petunjuk dari al-Quran secara maksimal. Jabatan lain di luar kampus yang pernah diembannya, antara lain: Ketua Majlis Ulama Indonesia (MUI) Pusat sejak 1984, anggota Lajnah Pentashih al-Qur-an Departemen Agama sejak 1989, selain itu ia banyak berkecimpung dalam berbagai organisasi profesional, seperti pengurus perhimpunan ilmu-ilmu Alquran Syari'ah, Pengurus Konsorsium Ilmu Ilmu Agama Departemen Pendidikan dan Kebudayaan, dan Asisten Ketua Umum Ikatan Cendekiawan Muslim Indonesia (ICMI). Serta direktur Pendidikan Kader Ulama (PKU) yang merupakan usaha MUI untuk membina kader-kader ulama di Tanah Air. ${ }^{32}$

Pada tahun 1998, tepatnya di akhir pemerintahan Orde Baru, ia pernah dipercaya sebagai Menteri Agama oleh Presiden Suharto, kemudian pada 17 Februari 1999, dia mendapat amanah sebagai Duta Besar Indonesia di Mesir. Walaupun berbagai kesibukan sebagai Konsekwensi jabatan yang diembannya, M. Quraish Shihab tetap aktif dalam kegiatan tulis menulis di berbagai media massa dalam rangka menjawab permasalahan yang berkaitan dengan persoalan agama.

Di Harian Pelita, ia mengasuh rubrik ,Tafsir Amanah ${ }^{e}$ dan juga menjadi anggota dewan Redaksi Majalah Ulum Alquran dan Mimbar Ulama di Jakarta. Dan kini, aktivitasnya adalah Guru Besar Pascasarjana UIN Syarif Hidatatullah Jakarta dan Direktur Pusat Studi Alquran (PSQ) Jakarta. ${ }^{33}$

\footnotetext{
${ }^{32}$ Artik Wartini, , Tafsir feminis m.Quraish shihab: Telaah ayat-ayat Gender dalam Tafsir almisbahe, h. 115. Lihat juga: M. Quraish Shihab, Lentera Hati : Kisah dan Hikmah Kehidupan, h. 5. Lihat juga: M. Quraish Shihab, Secercah Cahaya Ilahi : Hidup Bersama Al-Quran, Edisi Baru,, h. 5. Lihat juga: M. Quraish Shihab, Wawasan Al-Quran, Edisi Baru, h. v.

${ }^{33}$ Artik Wartini, , Tafsir feminis m.Quraish shihab: Telaah ayat-ayat Gender dalam Tafsir almisbah', h. 115. Lihat juga: M. Quraish Shihab, Lentera Hati : Kisah dan Hikmah Kehidupan, h. 5. Lihat juga: M. Quraish Shihab, Secercah Cahaya Ilahi : Hidup Bersama Al-Quran, Edisi Baru,, h. 5. Lihat juga: M. Quraish Shihab, Wawasan Al-Quran, Edisi Baru, h. v.
} 


\section{PEMBAHASAN}

\section{Prejudice and Communication Ethics Menurut Muhammad Quraish Shihab}

Alquran menegaskan tentang mutlaknya perbedaan, yang seringkali menjadi faktor penyebab kesalahpahaman. Allah swt berulang-kali menyebutkan dalam Alquran perihal ini, sebagaimana pembahasan pada bab sebelumnya. Namun pada realitasnya perselisihan itu semakin membesar hingga menimbulkan konflik berkepanjangan.

Sejatinya Alquran telah berbicara tentang sikap-sikap yang harus dilakukan guna memelihara kedamaian di tengah perbedaan tersebut.Surah AlHujurat memiliki hubungan dengan surah-surah sebelumnya, bahwa surah Muhammad menguraikan tentang peperangan.Selanjutnya, Surah Al-Fath tang berbicara kemenangan.Kandungan Surah Al-Hujurat adalah memberikan tuntunan terkait akhlak, sopan santun dalam ucapan maupun perbuatan. ${ }^{34}$ Ada dua poin penting yang terdapat dalam QS al-Hujurat ayat 11-12, yakni etika komunikasi dan etika prasangka.

1. Etika Komunikasi

Komunikasi merupakan kunci utama dalam kehidupan manusia.Oleh sebab itu, Allah telah memberikan patokan-patokan untuk diperhatikan manusia. Sebagaimana Firman Allah dalam Al Hujurat ayat 11 yang artinya,

Hai orang-orang yang beriman janganlah suatu kaum mengolok-olok kaum yang lain, boleh jadi mereka lebih baik dari mereka, dan jangan pula wanita terhadap wanita lain, boleh jadi mereka lebih baik daripada mereka dan janganlah kamu mengejek diri kamu sendiri dan janganlah kamu memanggil dengan gelar-gelar yang buruk.seburuk-buruk panggilan ialah kefasikan sesudah iman, dan barang siapa tidak bertaubat, maka mereka itulah orang-orang zalim.

Ayat di atas memiliki beberapa kandungan; pertama, tidak boleh mengolok-olok siapa pun. Menurut Quraish Shihab, dampak dari mengejek orang lain dapat menimbulkan pertikaian dan keretakan hubungan antar-

${ }^{34}$ M. Quraish Shihab. Tafsir Al-Mishbah: Pesan, Kesan dan Keserasian al-Qur'an (Ciputat: Lentera Hati, 2011), vol.12, hal. 573. 
mereka. Mengejek dapat secara sembunyi-sembunyi, dengan ucapan, perbuatan, ataupun isyarat. Memperolok-olokkan yaitu menyebut kekurangan pihak lain dengan tujuan menertawakan yang bersangkutan Sesungguhnya dampak dari mengejek itu sendiri dapat menimpa diri sendiri, mengejek orang lain sama halnya mendoakan keburukan untuk pribadi ${ }^{35}$

Kedua, tidak boleh memanggil dengan panggilan yang buruk atau pun dinilai buruk. Jika ditinjau dari asal katanya, at-tanabuz adalah saling member gelar yang buruk. Ada banyak riwayat yang menyebutkan sabab nuzul ayat ini. Salah satunya, ejekan yang dilakukan oleh Bani Tamim terhadap Bilal, Shuhaib dan Ammar yang merupakan orang kurang mampu. Juga berkaitan dengan ejekan yang dilakukan oleh Tsabit Ibn Qais kepada orang yang menegur dengan menyebutkan aibnya. ${ }^{36}$

2. Etika Prasangka

Prasangka merupakan suatu hal yang tidak dapat dihindari, akan tetapi dapat dikontrol dengan baik. Ayat selanjutnya pada QS Al-Hujurat berbicara mengenai etika dala berprasangka.Sehingga dengan acuan dasar Alquran diharapkan prasangka tersebut tidak menjadi pemicu konflik. Sebagaimana Firman Allah dalam QS Al-Hujurat ayat 12 yang artinya :

Hai orang-orang beriman, jauhilah banyak dari dugaan, sesungguhnya sebagian dugaan adalah dosa dan janganlah kamu mencari-cari kesalahan orang lain serta jangan sebagian kamu menggunjing sebagian yang lain. Sukakah salah seorang di antara kamu memakan daging saudaranya yang sudah mati?Maka kamu telah jijik kepadanya dan bertakwalah kepada Allah.Sesungguhnya Allah Maha Penerima taubat lagi Maha penyayang.

Ayat di atas menerangkan beberapa poin perilaku yang harus diaplikasikan dalam kehidupan sehari-hari. Pertama, menjauhi berprasangka buruk terhadap orang lain tanpa memiliki dasar apapun. Berprasangka buruk dapat menimbulkan ketegangan-ketegangan yang tiada henti di masyarakat.

35 M. Quraish Shihab. Tafsir Al-Mishbah: Pesan, Kesan dan Keserasian al-Qur'an (Ciputat: Lentera Hati, 2011), vol.12, hal. 605.

${ }^{36}$ M. Quraish Shihab. Tafsir Al-Mishbah... hal. 607-608. 
Kata ijtanibu memiliki tambahan huruf ta yang berfungsi sebagai penekanan, berarti upaya sungguh-sungguh untuk menghindari prasangka buruk. ${ }^{37}$

Kedua, dilarang mencari-cari kesalahan orang lain. Mencari informasiinformasi yang bersifat negatif pada diri seseorang maupun kelompok, dengan cara sembunyi maupun terbuka. Jika setiap orang berhak menyembunyikan apa yang enggan diketahui orang lain, maka janganlah berusaha menyingkap apa yang disembunyikannya. Mencari kesalahan orang lain biasanya lahir dari dugaan negatif. Oleh sebab itulah Allah telah melarang dari sifat mendugaduga. ${ }^{38}$ Hal ini dapat merenggangkan hubungan di masyarakat, seperti yang tejadi belakangan ini.

Ketiga, dilarang menggunjing yakni membicarakan orang lain. Menggunjing artinya menyebut orang lain yang tidak hadir dihadapan penyebutnya dengan sesuatu yang tidak disenangi oleh yang bersangkutan. Jika faktanya tidak benar, maka namanya adalah fitnah atau kebohongan besar. $^{39}$

Sebagaimana hadis-hadis berikut,

Dari Abu Hurairah, Rasulullah bersabda, "Janganlah kalian berprasangka buruk, karena sesungguhnya prasangka buruk adalah perkataan yang paling dusta. Janganlah saling memata-matai, janganlah saling mencari-cari kesalahan sesama, janganlah saling mendengki, membenci dan berbuat maker, melainkan jadilah hambahamba yang bersaudara." 40

Dari Anas, Rasulullah bersabda, "Janganlah kalian saling memboikot, janganlah saling membelakangi, janganlah saling membenci, dan janganlah saling hasud. tapi jadilah hamba-hamba Allah yang bersaudara dan tidaklah halal bagi seorang muslim untuk bersikap diam terhadap saudaranya lebih dari tiga hari.",41

\footnotetext{
${ }^{37}$ M. Quraish Shihab. Tafsir Al-Mishbah... hal. 608-609.

${ }^{38}$ M. Quraish Shihab. Tafsir Al-Mishbah... hal. 609-610.

${ }^{39}$ M. Quraish Shihab. Tafsir Al-Mishbah... hal. 611.

40 Baca Shahih Al-Bukhari (6066), Muslim (2563) dan Abu Daud (4917). Lihat, Muhammad Nashiruddin Albani, Derajat Hadis-hadis dalam Tafsir Ibn Katsir (Jakarta: Pustaka Azzam, 2008), hal. 218.

${ }^{41}$ Lihat Muhammad Nashiruddin Albani, Derajat Hadis-hadis dalam Tafsir Ibn Katsir....hal. 219
} 
Kandungan QS Al-Hujurat ayat 11-12 berisi larangan-larangan untuk berbuat zalim terhadap sesama manusia dengan merujuk pada etika komunikasi dan prasangka. Jika etika ini dapat dijaga dengan baik, maka berita hoax tidak akan bertebaran di jejaring social, pemicu konflik juga dapat diredam. Sesungguhnya kerusuhan yang terjadi di masyarakat ditimbulkan oleh prasangka buruk, menjelek-jelekkan dan sebagainya.

\section{SIMPULAN}

Konflik yang terjadi ditengah masyarakat tidaklah disebabkan oleh keragaman yang secara pasti disebutkan dalam Alquran. Konflik berawal dari kesalahpahaman, kerenggangan sosial, dan ketidaknyamanan. Di abad 21-22 ini masyarakat tengah disibukkan dengan konflik yang terjadi di jejaring sosial. Ledakan pemicu yang disebarkan media online kerapkali menyulut emosi warganet, langsung maupun tidak langsung. Alquran dengan jelas menyebutkan undang-undang terkait etika dalam berkomunikasi sebagai resolusi atas konflik era ini. Surah Al-Hujurat ayat 11-12 menjadi landasan pokok atas permasalahan tersebut. Ada beberapa poin penting yang dapat diambil dari ayat tersebut. Pertama, tidak boleh mengolok-olok siapa pun. Kedua, tidak boleh memanggil dengan panggilan yang buruk atau pun dinilai buruk. Ketiga, menjauhi berprasangka buruk terhadap orang lain. Keempat, dilarang mencari-cari kesalahan orang lain. Kelima, dilarang menggunjing. Kendati pembahasan ini sudah menjadi pembahasan dan konsumsi publik, namun dalam prakteknya masyarakat Indonesia di era milenial tidak dapat dipisahkan dari prejudice dan kesalahan fatal yang berlandaskan emosi semata.

\section{DAFTAR PUSTAKA}

Abdullah bin Ishaq. Lubaabut Tafsir Min Ibni Katsiir, terj. M. Abdul Ghoffar. Jakarta: Pustaka Imam Asy-Syafi' I, 2013. 
Aunur Rofiq. Tafsir Resolusi Konflik: Model Manajemen Interaksi dan Deradikalisasi Beragama Perspektif al-Qur'an dan Piagam Madinah. Malang: UIN Maliki 2011.

Charles Kimball. Kala Agama Menjadi Bencana. Jakarta: Mizan Publika. 2013.

Dadang Kahmad. Sosiologi Agama. Bandung: Remaja Rosdakarya. 2009.

Departemen Agama RI. Konflik Sosial Bernuansa Agama di Indonesia. Jakarta: Balitbang Agama. 2003.

Dian Maya Safitri. "Belajar tentang Nilai-nilai Pluralisme Islam Jenderal Cheng Ho", Kumpulan Makalah the $10^{\text {th }}$ Annual Conference on Islamic Studies, Banjarmasin 1-4 November 2010.

Fakhrie Hanif. "Toleransi dalam Alquran”. Al-Nahdhah, Vol III No 3, 2009.

Fakhruddin ar-Razi, Mafaatih al-Ghaib. Beirut: Dar al-Fikr, 1995.

Fazlur Rahman. Tema Pokok Alquran, terj. Anas Mahyuddin. Bandung: Pustaka. 1980.

Hamka. Tafsir Al-Azhar Juz XII. Jakarta: Pustaka Panjimas, 2002.

Kamil. Pluralisme Agama dan Resolusi Konflik: Kontribusi TH. Sumarta bagi Resolusi Konflik di Maluku. Jakarta: Sedaun. 2011.

Kutbuddin Aibak. Teologi Pembacaan: dari Tradisi Pembacaan Paganis Menuju Rabbani. Yogyakarta: Teras. 2009.

Luluk Fikri Zuhriyah. "Metode dan Pendekatan dalam Studi Islam: Pembacaan atas Pemikiran Charles J. Adams". Islamica: Jurnal Studi Keislaman. Vol. 2 No 1 September 2007.

M. Quraish Shihab. Tafsir Al-Mishbah: Pesan, Kesan dan Keserasian al-Qur'an. Ciputat: Lentera Hati, 2011.

Muhammad Chirzin. "Keanekaragaman dalam Alquran”, Jurnal Tsaqafah, Vol 7, No 1, April 2011.

Muhammad Nashiruddin Albani, Derajat Hadis-hadis dalam Tafsir Ibn Katsir. Jakarta: Pustaka Azzam, 2008.

Nur Muhammad Wahyu Kuncoro. 69 Kasus Hukum Mengguncang Indonesia. Depok: Penebar Swadaya Grup. 2012. 
Said Ramadhan Al-Buthy. Fikih Sirah: Hikmah Tersirat dalam Lintas Sejarah Hidup Rasulullah, terj. Fuad Syaifudin Nur. Jakarta: Mizan Publika, 2010. Sayyed Hoessein Nasr. Islam Cita dan Islam Fakta. Jakarta: Yayasan Obor. 1984. Tempo; Mengulik Dunia Digital Indonesia (3 September 2017), Membajak Akun Menabur Benci (3 September 2017), Dusta di atas Derita: Kabar Bohong tentang Krisis Rohingya (17September 2017), Sang Jenderal dan Kontroversinya (8 Oktober 2017).

Zainal Abidin Ahmad. Piagam Nabi Muhammad: Konstitusi Negara Tertulis yang Pertama di Dunia. Jakarta: Bulan Bintang, 1973.

Zuhairi Misrawi. Alquran Kitab Toleransi: Inklusivisme, Pluralisme dan Multikulturalisme. Jakarta: Fitrah, 2007. 